\title{
IR-Spectroscopic Study on the Interface of Cu-Based Methanol Synthesis Catalysts: Evidence for the Formation of a $\mathrm{ZnO}$ Overlayer
}

\author{
Julia Schumann ${ }^{1,3,4} \cdot$ Jutta Kröhnert $^{1} \cdot$ Elias Frei $^{1} \cdot$ Robert Schlögl $^{1,2}$ • \\ Annette Trunschke ${ }^{1}$
}

Published online: 28 August 2017

(C) The Author(s) 2017. This article is an open access publication

\begin{abstract}
Carbon monoxide was applied as probe molecule to compare the surface of a $\mathrm{ZnO}$-containing $(\mathrm{Cu} /$ $\mathrm{ZnO}: \mathrm{Al})$ and a $\mathrm{ZnO}$-free $(\mathrm{Cu} / \mathrm{MgO})$ methanol synthesis catalyst (copper content 70 atomic \%) after reduction in hydrogen at $523 \mathrm{~K}$ by DRIFT spectroscopy. Nano-structured, mainly metallic copper was detected on the surface of the $\mathrm{Cu} / \mathrm{MgO}$ catalyst. In contrast, the high energy of the main peak in the spectrum of $\mathrm{CO}$ adsorbed on reduced $\mathrm{Cu} /$ $\mathrm{ZnO}: \mathrm{Al}\left(2125 \mathrm{~cm}^{-1}\right)$ proves that metallic copper is largely absent on the surface of this catalyst. The band is assigned to $\mathrm{Zn}^{\delta+}-\mathrm{CO}$. The presence of not completely reduced $\mathrm{Cu}^{\delta+}-$ $\mathrm{CO}$ species cannot be excluded. The results are interpreted in terms of a partial coverage of the copper nano-particles in the $\mathrm{Cu} / \mathrm{ZnO}: \mathrm{Al}$ catalyst by a thin layer of metastable,
\end{abstract}

In memoriam Prof. Dr. Helmut Knözinger.

Electronic Supplementary Material The online version of this article (doi:10.1007/s11244-017-0850-9) contains supplementary material, which is available to authorized users.

Elias Frei

efrei@ fhi-berlin.mpg.de

$\triangle$ Annette Trunschke

trunschke@fhi-berlin.mpg.de

1 Department of Inorganic Chemistry, Fritz-Haber-Institut der Max-Planck-Gesellschaft, Faradayweg 4-6, 14195 Berlin, Germany

2 Max Planck Institute for Chemical Energy Conversion, Stiftstr. 34-36, 45470 Mülheim, Germany

3 Present Address: Department of Chemical Engineering, Stanford University, 443 Via Ortega, Stanford, CA 94305, USA

4 SLAC National Accelerator Laboratory, SUNCAT Center for Interface Science and Catalysis, 2575 Sand Hill Road, Menlo Park, CA 94025, USA defective zinc oxide. Minor contributions in the spectrum at 2090 and $2112 \mathrm{~cm}^{-1}$ due to nano-structured $\mathrm{Cu}^{0}-\mathrm{CO}$ and $\mathrm{CO}$ adsorbed on highly defective $\mathrm{Cu}^{0}$, respectively, indicate that the coverage of metallic copper is not complete.

Keywords $\mathrm{Cu} \cdot$ Methanol synthesis catalyst $\cdot \mathrm{CO}$ adsorption $\cdot$ DRIFTS

\section{Introduction}

Climate change and the limited availability of fossil fuels drive the development of renewable energy sources. The fluctuations of renewable energy require efficient energy storage for a viable renewable future energy scenario. One promising possibility is the conversion of electrical energy into chemical energy in molecules such as methanol using $\mathrm{CO}_{2}$ as feedstock. Despite the large-scale application of methanol synthesis over $\mathrm{Cu} / \mathrm{ZnO} / \mathrm{Al}_{2} \mathrm{O}_{3}$ catalysts for several decades, understanding of the unique $\mathrm{Cu}-\mathrm{ZnO}$ synergy that renders this catalyst active is still incomplete. However, this understanding is crucial in order to optimize the catalyst to the special conditions needed for methanol synthesis from a $\mathrm{CO}_{2}$ based feed and to application under dynamic operation conditions.

Infrared spectroscopy is a powerful tool to investigate oxides or supported metal catalysts [1-4]. Indirect information concerning nature and number of adsorption sites at the surface of the catalyst is retrieved by adsorption of appropriate probe molecules. Carbon monoxide has been used frequently as a probe molecule based on non-reactive adsorption at cationic sites, [4] the formation of carbonyls with metals, $[5,6]$ and the weak interaction with hydroxyl groups $[2,7]$. Alterations of the probed surface by possible redox reactions of $\mathrm{CO}$ with surface sites or the formation 
of volatile carbonyls [8] can be prevented by adsorption at liquid nitrogen temperature.

Due to the high copper content (50-70 wt \%) in industrial relevant $\mathrm{Cu} / \mathrm{ZnO} / \mathrm{Al}_{2} \mathrm{O}_{3}\left(\mathrm{Al}_{2} \mathrm{O}_{3}\right.$ as phase, higher $\mathrm{Al}$-content of 10-15 wt\%) methanol synthesis catalysts, infrared studies of probe molecule adsorption on realistic systems and operando investigations are, however, limited [9-12]. Frequently, FTIR studies have been performed on model catalysts with lower copper contents or after dilution [13-19].

Recently, a $\mathrm{Cu} / \mathrm{ZnO}: \mathrm{Al}$ ( $\mathrm{Al}$ as dopant in the $\mathrm{ZnO} ; \mathrm{ZnO}: \mathrm{Al}$, lower Al-content of $<3 \mathrm{wt} \%$ ) catalyst has been compared with a $\mathrm{Cu} / \mathrm{MgO}$ catalyst in methanol synthesis [20-22]. The $\mathrm{Cu}$ nano-structure in $\mathrm{Cu} / \mathrm{ZnO}: \mathrm{Al}$ and $\mathrm{Cu} / \mathrm{MgO}$ is almost identical due to the common malachite-based precursor structure [20]. Despite similar Cu-content and specific surface area, the $\mathrm{Cu} / \mathrm{MgO}$ catalyst showed a seven times higher activtiy in a $\mathrm{CO} / \mathrm{H}_{2}$ feed, [22] and almost no activity in a $\mathrm{CO} / \mathrm{CO}_{2} / \mathrm{H}_{2}$-feed, confirming the needed $\mathrm{Cu}-\mathrm{ZnO}$ synergy in particular for the $\mathrm{CO}_{2}$ activation [23-28] that may be attributed to different reasons including a wetting of $\mathrm{Cu}$ by (layered-) $\mathrm{ZnO}$ under reaction conditions. The coverage of the $\mathrm{Cu}$-surface by a $\mathrm{ZnO}$ overlayer, as possible reason for the poor activity in a $\mathrm{CO} / \mathrm{H}_{2}$ feed, has been recently visualized by high-resolution transmission electron microscopy (HRTEM) studies of a reduced $\mathrm{Cu} / \mathrm{ZnO}: \mathrm{Al}$ catalyst [29]. Strong metal-support interaction (SMSI) is apparently implemented by the formation of a thin layer of metastable "graphitic - / boron nitride-like" $\mathrm{ZnO}$ on the surface of the copper particles after reductive activation of the catalyst.

Local insight into the nano-structure by electron microscopy is complemented in the present contribution by a diffuse reflectance infrared Fourier transform (DRIFT) spectroscopy study. Infrared spectroscopy of adsorbed carbon monoxide provides integral information regarding nature and abundance of adsorption sites. The surface of $\mathrm{Cu} /$ $\mathrm{ZnO}: \mathrm{Al}$ and $\mathrm{Cu} / \mathrm{MgO}$ catalysts are compared with a special focus on the metal/metal oxide interface and the accessibility of the $\mathrm{Cu}$ moieties.

\section{Experimental}

\subsection{Catalyst Synthesis}

Calcined $\mathrm{CuO} / \mathrm{ZnO}: \mathrm{Al}$ and $\mathrm{CuO} / \mathrm{MgO}$ precursors that contain a similar amount of $\mathrm{Cu}$ were prepared by constant $\mathrm{pH}$ co-precipitation $[20,21]$. The zincian malachite precursor with a $\mathrm{Cu}: \mathrm{Zn}$ ratio of 70:30 and $3 \mathrm{~mol} \%$ (metal base) $\mathrm{Al}$ was synthesized by co-precipitation from a $\mathrm{Cu}, \mathrm{Zn}, \mathrm{Al}$ nitrate solution (1 M metal-based) and a $1.6 \mathrm{M} \mathrm{Na}_{2} \mathrm{CO}_{3}$ solution as a basic precipitating agent in an automated laboratory reactor setup (Labmax, Mettler Toledo). While stirring at $300 \mathrm{rpm}$, the metal nitrate solution $(600 \mathrm{~g})$ was dosed at a temperature of $338 \mathrm{~K}$. The $\mathrm{pH}$ was controlled by a feedback loop through simultaneous addition of the $\mathrm{Na}_{2} \mathrm{CO}_{3}$ solution at $\mathrm{pH}$ 6.5. After $30 \mathrm{~min}$ the dosing was complete. Ageing was pursued for $80 \mathrm{~min}$, then the slurry was filtrated and the precipitate was washed until the conductivity of the filtrate was below $0.5 \mathrm{mS} \mathrm{cm}^{-1}$. Spray-drying yielded the greenishblue-colored precursor powder. For the preparation of the zinc-free $\mathrm{Cu} / \mathrm{MgO}$ catalyst, a $\mathrm{Cu}, \mathrm{Mg}$ nitrate solution with a Cu:Mg ratio of 70:30 was used. The co-precipitation was performed at $\mathrm{pH}$ 9. Subsequent synthesis steps were identical to the preparation of the $\mathrm{Cu} / \mathrm{ZnO}: \mathrm{Al}$ precursor.

The precursors were calcined in a rotary furnace in a flow of $125 \mathrm{~mL} \mathrm{~min}^{-1}$ of $20 \% \mathrm{O}_{2}$ in Ar at $603 \mathrm{~K}$ for $3 \mathrm{~h}$ and a heating rate of $2 \mathrm{~K} \mathrm{~min}^{-1}$. Reduction of the calcined precursors was performed in-situ in the cell for DRIFTS measurements.

\subsection{DRIFTS Measurement}

Diffuse reflectance infrared Fourier transform (DRIFT) spectra were collected on a Cary 600 Series FTIR Spectrometer from Agilent Technologies equipped with a liquid nitrogencooled MCT detector at a spectral resolution of $2 \mathrm{~cm}^{-1}$ and accumulation of 512 scans. An in-situ cell (Harrick Praying Mantis ${ }^{\mathrm{TM}}$ diffuse reflectance attachment DRP-DF8 in combination with a low temperature CHC-CHA-3 reaction chamber) was used. Prior to the measurements the optical path was aligned. The contribution of specular reflected light directed to the detector was minimized by using a mirror in sample position.

Spectra were taken at 77 or $300 \mathrm{~K}$, respectively, after appropriate pretreatment in the reaction chamber. The calcined precursors were dehydrated in the DRIFTS cell by treatment in $4 \% \mathrm{O}_{2}$ in $\mathrm{Ar}$ at $423 \mathrm{~K} .5 \% \mathrm{H}_{2}$ in $\mathrm{Ar}$ gas flow was used to reduce the calcined precursors with a heating rate of $6 \mathrm{~K} \mathrm{~min}^{-1}$ up to $523 \mathrm{~K}$. The temperature was kept at $523 \mathrm{~K}$ for $30 \mathrm{~min}$, then hydrogen was switched off and the sample was cooled down to $298 \mathrm{~K}$ in Ar. At room temperature, the DRIFTS cell was evacuated until a pressure of $10^{-5}$ mbar. The spectra of the two catalysts after reduction measured in diffuse reflection using $\mathrm{KBr}$ as background are presented in the Supporting Information (Fig. S1). Despite the low reflectance $(<0.1 \%)$ the quality of the spectra is high. Furthermore, the reflectance of the two reduced catalysts in the frequency range of $\mathrm{C}-\mathrm{O}$ stretching vibrations $\left(2150-1950 \mathrm{~cm}^{-1}\right)$ is comparable.

The single-beam spectrum of the corresponding pretreated catalyst was used as background to generate the spectrum of adsorbed $\mathrm{CO}$. The spectra of adsorbed $\mathrm{CO}$ are presented in Kubelka-Munk units $F\left(R_{\infty}\right)=\left(1-R_{\infty}\right)^{2} / 2 R_{\infty}$ [30-32]. CO isotherms were recorded by dosing $\mathrm{CO}$ at increasing equilibrium pressures ranging from 0.1 to 
80 mbar. For each experiment a freshly pretreated sample was used.

\section{Results}

The general characteristics of the investigated samples within this DRIFTS study are summarized in Table 1 . The nano-structure of copper oxide in the two calcined precursors is very similar leading to comparable $\mathrm{Cu}$ domain sizes in the reduced catalysts as revealed by XRD, regardless whether $\mathrm{ZnO}: \mathrm{Al}$ or $\mathrm{MgO}$ was used as spacer. The XRD data are measured under in-situ conditions and the patterns

Table 1 Chemical composition, surface areas and particle size of $\mathrm{Cu}$ particles in $\mathrm{Cu} / \mathrm{ZnO}: \mathrm{Al}$ and $\mathrm{Cu} / \mathrm{MgO}$

\begin{tabular}{|c|c|c|}
\hline & $\mathrm{Cu} / \mathrm{ZnO}: \mathrm{Al}$ & $\mathrm{Cu} / \mathrm{MgO}$ \\
\hline ID of calcined catalyst ${ }^{\mathrm{a}}$ & 19,081 & 19,802 \\
\hline XRF metal-based (atom\%) & $68 / 29 / 3$ & $70 / 30$ \\
\hline BET precursor/calcined catalyst $\left(\mathrm{m}^{2} \mathrm{~g}^{-1}\right)$ & $128 / 123$ & $114 / 116$ \\
\hline $\mathrm{Cu}$ domain size reduced catalyst $(\mathrm{nm})^{\mathrm{b}}$ & $5.5 / 7.7$ & $9.3 / 13.0$ \\
\hline $\mathrm{Cu}$ particle size TEM (nm) & $8.1[21]$ & n.d. \\
\hline $\mathrm{Cu}$ surface area $\mathrm{N}_{2} \mathrm{O}\left(\mathrm{m}^{2} \mathrm{~g}^{-1}\right)$ & $36[33]$ & $24[33]$ \\
\hline $\mathrm{Cu}$ surface area $\mathrm{H}_{2}\left(\mathrm{~m}^{2} \mathrm{~g}^{-1}\right)^{\mathrm{c}}$ & $16[33]$ & $24[33]$ \\
\hline Catalytic activity $\left[\mu \mathrm{mol}_{\mathrm{MeOH}}\left(\mathrm{g}_{\mathrm{cat}} \min \right)^{-1}\right]^{\mathrm{d}}$ & 55 & 350 \\
\hline Catalytic activity $\left[\mu \mathrm{mol}_{\mathrm{MeOH}}\left(\mathrm{g}_{\mathrm{cat}} \min \right)^{-1}\right]^{\mathrm{e}}$ & 300 & 20 \\
\hline
\end{tabular}

${ }^{a}$ required to clearly distinguish different batches of catalyst synthesis

b determined by in-situ XRD measurements as $\mathrm{L}_{\mathrm{Vol}}-\mathrm{IB} / \mathrm{L}_{\mathrm{Vol}}-\mathrm{FWHM}$

${ }^{\mathrm{c}}$ surface area was determined assuming $\mathrm{Cu}: \mathrm{H}_{2}=3: 1$ stoichiometry, according to [33]

${ }^{\mathrm{d}} \mathrm{p}=30 \mathrm{bar}, \mathrm{T}=503 \mathrm{~K}$, feed $14 \% \mathrm{CO} / 59 \% \mathrm{H}_{2} / \mathrm{rest} \mathrm{He}$

${ }^{\mathrm{e}} \mathrm{p}=30$ bar, $\mathrm{T}=503 \mathrm{~K}$, feed $8 \% \mathrm{CO}_{2} / 6 \% \mathrm{CO} / 59 \% \mathrm{H}_{2} /$ rest $\mathrm{He}$

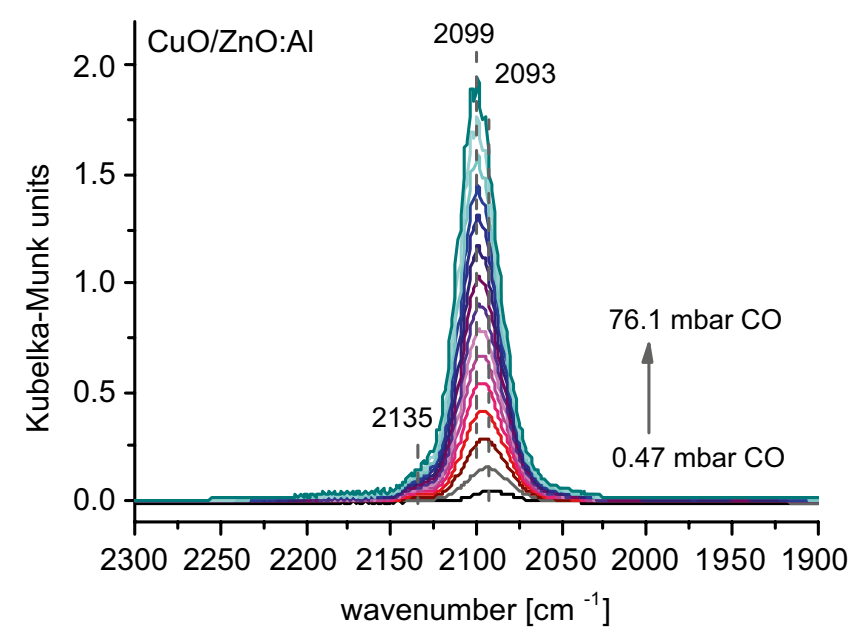

are shown in the Supporting Information (Fig. S2). The $\mathrm{Cu}$ domain size is given as volume weighted $\left(\mathrm{L}_{\mathrm{VOL}}-\mathrm{IB}\right)$ and Scherrer-equation based FWHM values. The $\mathrm{Cu}$ surface area is determined with $\mathrm{H}_{2}$-TPD measurement. The $\mathrm{N}_{2} \mathrm{O}$-surface area is in correlation to the redox active sites on the surface. That means if we have e.g. oxygen vacancies in the metal oxide component or the metal oxide is reducible, the $\mathrm{N}_{2} \mathrm{O}$ and the $\mathrm{H}_{2}$-TPD values are different. This is the case for $\mathrm{Cu} / \mathrm{ZnO}: \mathrm{Al}$, but not for $\mathrm{Cu} / \mathrm{MgO}$. The reactivity data show very clearly that for a fast $\mathrm{CO}_{2}$ hydrogenation $\mathrm{ZnO}$ has to be present and with a $\mathrm{ZnO}$-free $\mathrm{Cu} / \mathrm{MgO}$ only $\mathrm{CO}$ can be converted.

\subsection{CO Adsorption at $300 \mathrm{~K}$}

\subsubsection{CO Adsorption on the Calcined Precursors}

Spectra of $\mathrm{CO}$ adsorbed on the calcined precursors $\mathrm{CuO} /$ $\mathrm{ZnO}: \mathrm{Al}$ and $\mathrm{CuO} / \mathrm{MgO}$ (calcination at $603 \mathrm{~K}$ in synthetic air), respectively, are shown in Fig. 1. Bands due to adsorbed CO appear at the same positions for the two calcined precursors: a main signal at ca. $2100 \mathrm{~cm}^{-1}$ with a small shoulder at $2135 \mathrm{~cm}^{-1}$. The main peak shifts slightly from $2092 / 2093 \mathrm{~cm}^{-1}$ at very low CO coverage to higher wavenumbers with increasing $\mathrm{CO}$ coverage for both the $\mathrm{ZnO}$-free and $\mathrm{ZnO}$-containing calcined precursors.

The integrated $\mathrm{CO}$ bands were plotted against the respective equilibrium pressure to obtain $\mathrm{CO}$ adsorption isotherms. Adsorption isotherms normalized to full coverage $(\theta=1)$ are presented in the Supporting Information (Fig. S3, left). Both $\mathrm{CuO} / \mathrm{MgO}$ and $\mathrm{CuO} / \mathrm{ZnO}: \mathrm{Al}$ display the same shape of the $\mathrm{CO}$ adsorption isotherm. The overall adsorption capacity is comparable, although slightly higher for $\mathrm{CuO} / \mathrm{MgO}$ as it

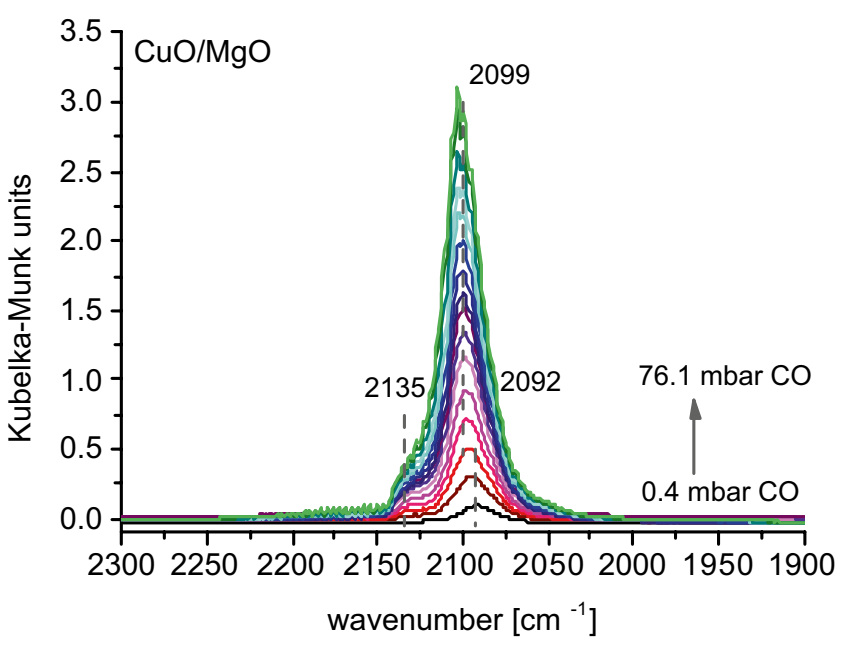

Fig. 1 Infrared spectra of $\mathrm{CO}$ adsorbed on the calcined precursors $\mathrm{CuO} / \mathrm{ZnO}: \mathrm{Al}$ (left), and $\mathrm{CuO} / \mathrm{MgO}$ (right) after evacuation at $423 \mathrm{~K}$ $\left(\mathrm{T}_{\mathrm{ads}}=300 \mathrm{~K}\right.$, increasing equilibrium pressures from 0.5 to $\left.76 \mathrm{mbar} \mathrm{CO}\right)$ 
becomes apparent from the direct comparison at $\theta=0.5$ in Fig. 5, left.

\subsubsection{CO Adsorption at $300 \mathrm{~K}$ on the Reduced Catalysts}

After reduction of the $\mathrm{CuO}$ containing calcined precursors in hydrogen containing feed at $523 \mathrm{~K}$ to bulk $\mathrm{Cu}$ metal, the $\mathrm{CO}$ band positions and adsorption capacity of the $\mathrm{ZnO}$-containing and $\mathrm{ZnO}$-free sample differ significantly (Fig. 2). The corresponding adsorption isotherms are shown in Fig. S3, right. The raw data (adsorption isotherms not normalized) are additionally presented in Fig. S4.

$\mathrm{CO}$ bands of the $\mathrm{ZnO}$-free sample $\mathrm{Cu} / \mathrm{MgO}$ (Fig. 2, right; Fig. 5, middle) appear mainly below $2100 \mathrm{~cm}^{-1}$. The main band is located at $2089 \mathrm{~cm}^{-1}$. With increasing coverage a shoulder at $2077 \mathrm{~cm}^{-1}$ develops that is shifted to $2060 \mathrm{~cm}^{-1}$ at $\theta=1$. No blue shift is observed with increasing coverage.

The overall intensity of the absorption bands of the $\mathrm{ZnO}$ containing $\mathrm{Cu} / \mathrm{ZnO}$ : $\mathrm{Al}$ catalyst is much weaker compared to $\mathrm{Cu} / \mathrm{MgO}$ (Fig. 2, left). More important, the main signal appears here at $2125 \mathrm{~cm}^{-1}$. At low coverage a signal at $2112 \mathrm{~cm}^{-1}$ can be distinguished with only very weak features at lower wavenumbers around $2090 \mathrm{~cm}^{-1}$. With increasing pressure, the gas phase $\mathrm{CO}$ vibration and a weak band at $1996 \mathrm{~cm}^{-1}$ become visible.

Direct comparison of the two catalysts at 50\% coverage is shown in Fig. 5 (middle). This figure clearly depicts the diminished adsorption capacity of the $\mathrm{Cu} / \mathrm{ZnO}: \mathrm{Al}$ catalyst and the differences in the band positions.

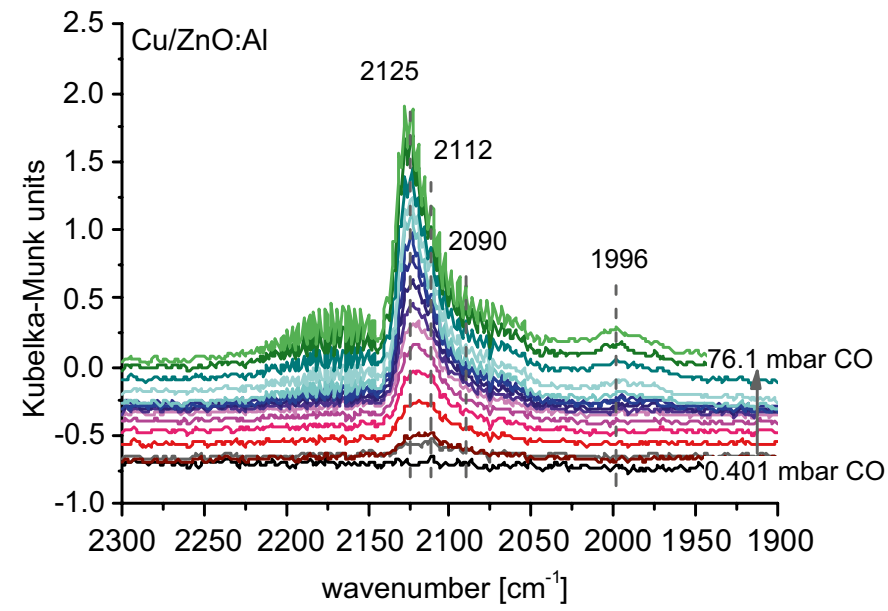

\subsubsection{CO Desorption Experiments at $300 \mathrm{~K}$ on the Reduced Catalysts}

Bands due to $\mathrm{CO}$ adsorption disappear rapidly upon evacuation at $300 \mathrm{~K}$ for both catalysts (Fig. 3). CO is slightly stronger adsorbed on $\mathrm{Cu} / \mathrm{MgO}$. After 3.5 min no signal due to $\mathrm{CO}$ adsorption is seen for $\mathrm{Cu} / \mathrm{ZnO}: \mathrm{Al}$, whereas for $\mathrm{Cu} /$ $\mathrm{MgO}$ a small signal can still be observed after $3.5 \mathrm{~min}$ in vacuum. The additional band at $1996 \mathrm{~cm}^{-1}$ only observed on $\mathrm{Cu} / \mathrm{ZnO}: \mathrm{Al}$ cannot be removed by evacuation at room temperature.

\subsection{CO Adsorption at $77 \mathrm{~K}$ on the Reduced Catalysts}

In addition to the measurements at $300 \mathrm{~K}, \mathrm{CO}$ adsorption spectra of the reduced catalysts were also recorded at liquid $\mathrm{N}_{2}$ temperature at $77 \mathrm{~K}$ (Fig. 4). The corresponding adsorption isotherms are presented in the Supporting Information (Fig. S5).

A band at $2091 \mathrm{~cm}^{-1}$ appears upon adsorption of $\mathrm{CO}$ on $\mathrm{Cu} / \mathrm{MgO}$ (Fig. 4, right), similar like in the adsorption experiment at $300 \mathrm{~K}$ (Fig. 2, right). A shoulder is observed at lower wavenumbers at around $2060 \mathrm{~cm}^{-1}$. Additionally, a weak signal arises at $2180 \mathrm{~cm}^{-1}$. This signal was not observed at room temperature. With increasing CO coverage, the peak maxima do not shift, but a weak shoulder of the main signal appears at higher wavenumbers around $2114 \mathrm{~cm}^{-1}$, much stronger pronounced compared to the spectra recorded at room temperature.

The $\mathrm{CO}$ adsorption spectra of the reduced $\mathrm{ZnO}$-containing catalyst differ strongly from the measurement at room temperature and show an increase in the absolute signal intensity (Fig. 4, left). At low coverage a main signal arises at $2096 \mathrm{~cm}^{-1}$. A weak signal is observed at

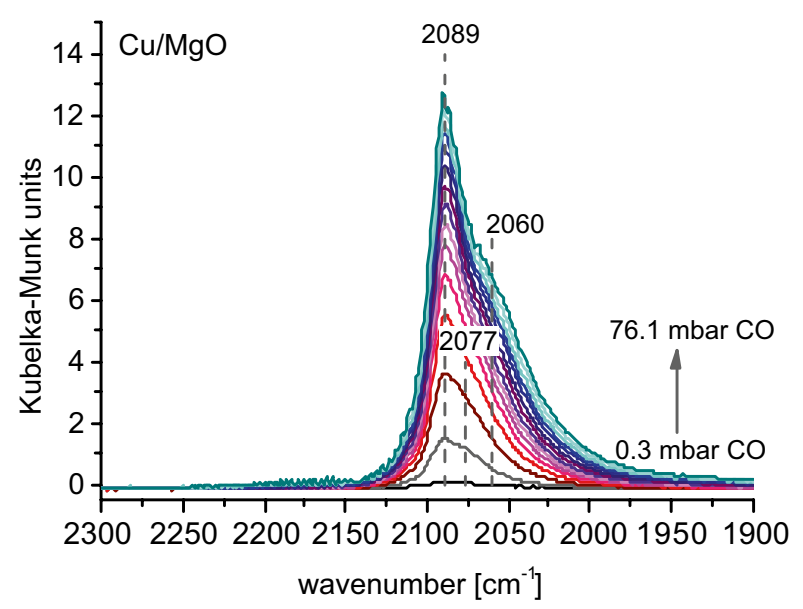

Fig. 2 Infrared spectra of $\mathrm{CO}$ adsorbed on the reduced catalysts $\mathrm{Cu} / \mathrm{ZnO}: \mathrm{Al}($ left $)$ and $\mathrm{Cu} / \mathrm{MgO}$ (right) after reduction of the catalysts at $523 \mathrm{~K}$ in the infrared chamber $\left(\mathrm{T}_{\mathrm{ads}}=300 \mathrm{~K}\right.$, increasing equilibrium pressures from 0.3 to $\left.76 \mathrm{mbar} \mathrm{CO}\right)$ 

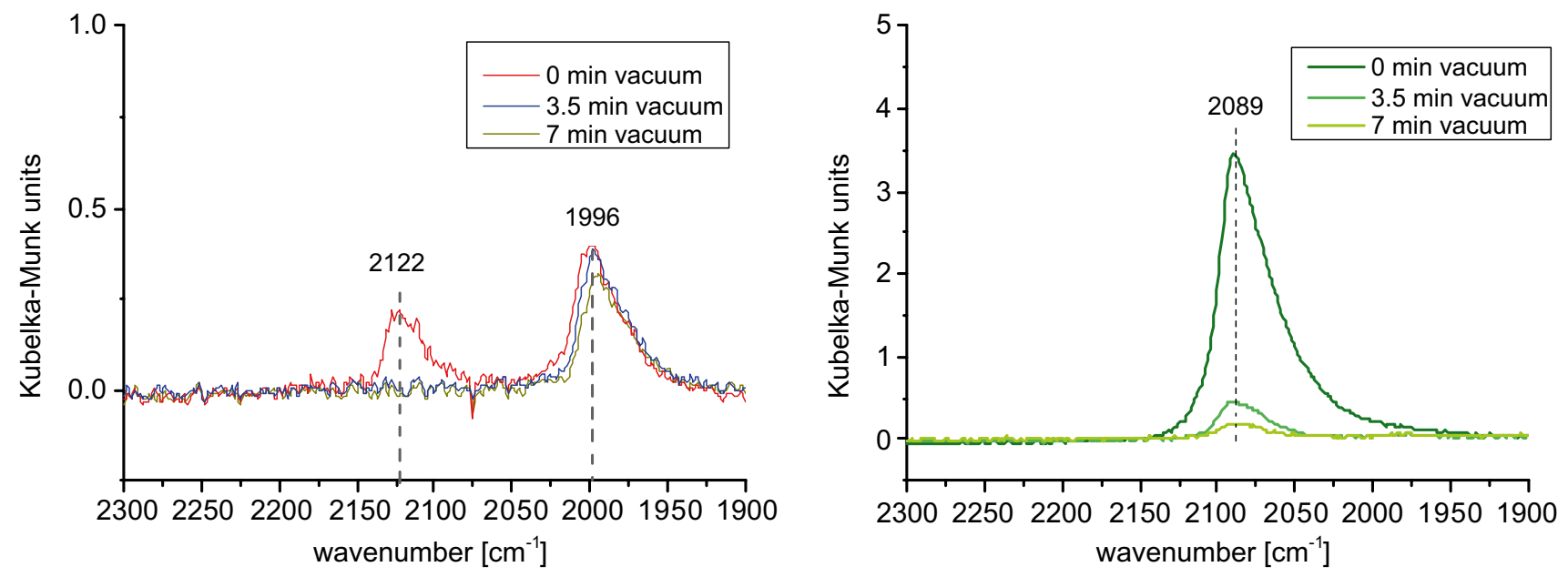

Fig. 3 Desorption of $\mathrm{CO}$ at $300 \mathrm{~K}$ on the reduced catalysts. Left $\mathrm{Cu} / \mathrm{ZnO}$ :Al catalyst. Right $\mathrm{Cu} / \mathrm{MgO}$ catalyst
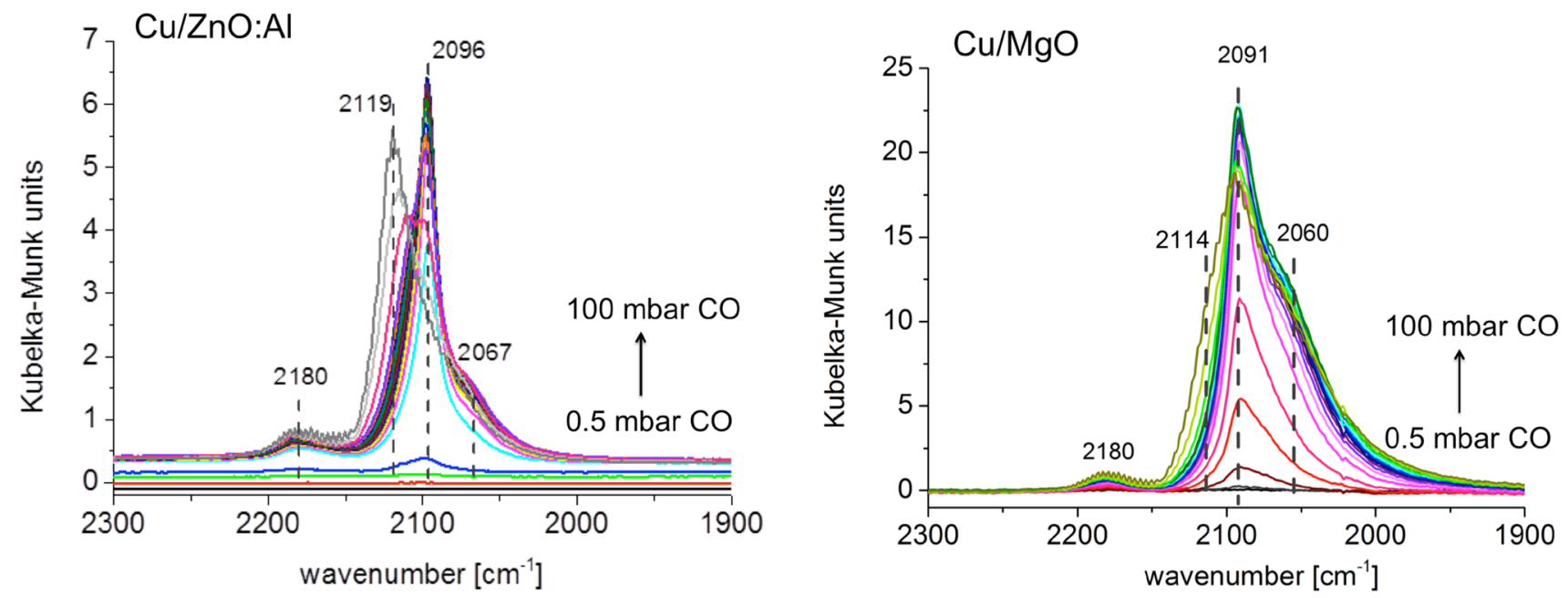

Fig. 4 Infrared spectra of $\mathrm{CO}$ adsorbed on $\mathrm{Cu} / \mathrm{MgO}$ (right) and $\mathrm{Cu} / \mathrm{ZnO}$ :Al (left) after reduction of the catalysts at $523 \mathrm{~K}$ in the DRIFTS cell $\left(\mathrm{T}_{\mathrm{ads}}=77 \mathrm{~K}\right.$, increasing equilibrium pressure from 0.1 to $\left.58 \mathrm{mbar} \mathrm{CO}\right)$
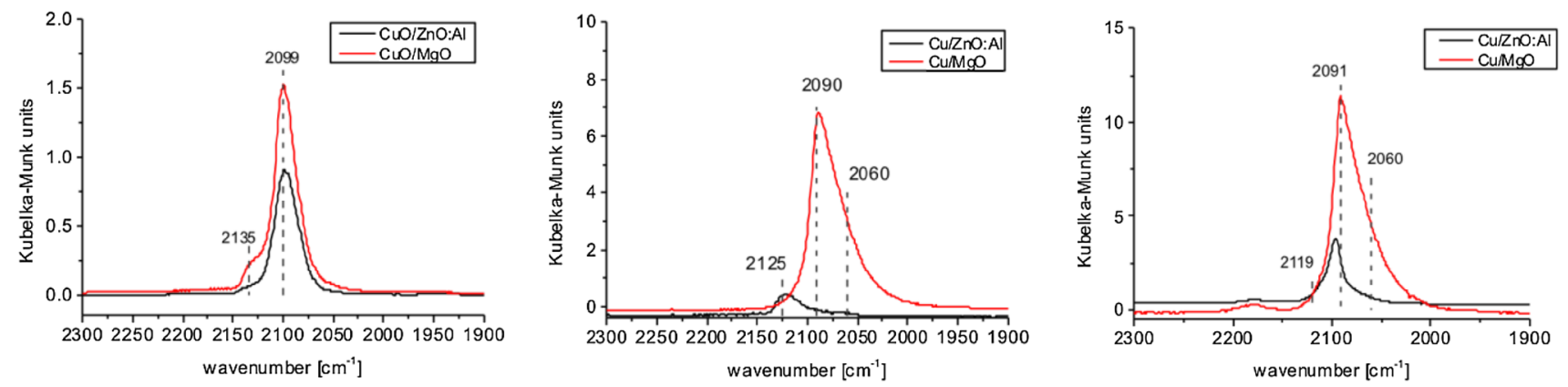

Fig. 5 DRIFT spectra of $\mathrm{CO}$ adsorbed at $300 \mathrm{~K}$ on the calcined precursors (left) and reduced catalysts (middle) and at $77 \mathrm{~K}$ on the reduced catalysts (right); the spectra have been recorded at a CO coverage of $0.5 \mathrm{ML}$ 
$2180 \mathrm{~cm}^{-1}$. Above a CO pressure of $5 \mathrm{mbar}$, the main signal at $2096 \mathrm{~cm}^{-1}$ decreases and a new signal at $2119 \mathrm{~cm}^{-1}$ arises and increases with increasing $\mathrm{CO}$ pressure.

\subsection{CO Adsorption on Reference Oxides}

$\mathrm{CO}$ was adsorbed on $\mathrm{CuO}$ and $\mathrm{ZnO}$ for reference (Fig. S6). $\mathrm{CO}$ adsorption at $300 \mathrm{~K}$ on $\mathrm{CuO}$ (Fig. S6, left) gives rise to $\mathrm{CO}$ stretching vibration at $2135 \mathrm{~cm}^{-1}$. CO adsorption on $\mathrm{ZnO}$ is very weak. In order to obtain a measurable signal the adsorption was performed at liquid $\mathrm{N}_{2}$ temperature (Fig. S6, right). A very weak signal at $2180 \mathrm{~cm}^{-1}$ was obtained.

\section{Discussion}

Assignment of $\mathrm{CO}$ band positions to $\mathrm{Cu}$ oxidation states and coordination numbers is by no means unambiguous and is further complicated by surface coverage dependencies of the band positions and the readiness of the $\mathrm{Cu}$ surface to react with $\mathrm{CO}$ [3]. The comparison of differently treated catalysts as well as the analysis of reference materials gave a better insight into the surface of $\mathrm{ZnO}$-containing vs. $\mathrm{ZnO}$-free $\mathrm{Cu}$ catalysts.

The stretching frequency regions of $\mathrm{Cu}^{\mathrm{n}+}-\mathrm{CO}$ surface carbonyl species with copper in different oxidation states overlap [3]. Generally, bands in the range $2220-2150 \mathrm{~cm}^{-1}$ have been assigned to $\mathrm{Cu}^{2+}-\mathrm{CO}$, whereas bands in the range $2160-2080 \mathrm{~cm}^{-1}$ are attributed to $\mathrm{Cu}^{+}-\mathrm{CO} . \mathrm{Cu}^{0}$ carbonyls including single-site and nanostructures species occur $<2130 \mathrm{~cm}^{-1}$.

$\mathrm{CO}$ adsorption on single crystal copper surfaces results in peaks $\leq 2100 \mathrm{~cm}^{-1}$ [34-37]. A difference of $26 \mathrm{~cm}^{-1}$ (2076-2102 $\mathrm{cm}^{-1}$ ) in the stretching frequency of linearly adsorbed $\mathrm{CO}$ has been reported for different crystal facets [36]. Low frequency bands can be assigned to terrace places on low-indexed $\mathrm{Cu}$ surface planes. High frequency bands are due to $\mathrm{CO}$ adsorbed on high-indexed $\mathrm{Cu}$ surface planes or defect sites. $\mathrm{CO}$ stretching frequencies at $v(\mathrm{CO})=1830$ and $1812 \mathrm{~cm}^{-1}$ have been associated with bridging species on the $\mathrm{Cu}(111)$ surface [37]. Furthermore, the band position of linearly adsorbed $\mathrm{CO}$ is affected by dipole coupling (blue shift with increasing coverage in absence of any variation in the electron exchange between the $\mathrm{CO}$ molecule and the metal) superimposed by gradual changes in the balance of $\sigma$ - and $\pi$-bonding components [38].

In spite of these complications, good accordance has been generally detected between the spectra of $\mathrm{CO}$ adsorbed on single crystal $\mathrm{Cu}$ surfaces on the one hand and nanostructured copper particles supported on oxides on the other hand, $[10,14-18,36]$ resulting in the general agreement that peaks $>2100 \mathrm{~cm}^{-1}$ are ascribed to $\mathrm{CO}$ adsorption on oxidized copper species $\mathrm{Cu}^{\mathrm{n}+}$, while peaks $<2100 \mathrm{~cm}^{-1}$ are due to $\mathrm{CO}$ adsorption on metallic copper.

According to $\mathrm{XRD}$, the calcined precursors contain a $\mathrm{CuO}$ phase (tenorite) as the only semi-crystalline phase [21]. Adsorption of $\mathrm{CO}$ on copper oxide at room temperature generally leads to the formation of $\mathrm{Cu}^{+}-\mathrm{CO}$ carbonyls [3]. In agreement with the literature, adsorption of $\mathrm{CO}$ on the reference $\mathrm{CuO}$ (Fig. S6) resulted in the formation of a weak signal at $2135 \mathrm{~cm}^{-1}$ that suggests the presence of $\mathrm{Cu}^{+}$. This band was also found in the spectra of the calcined precursors (Fig. 1). However, it contributes only as a weak shoulder to the intense signals with maxima at $2100 \mathrm{~cm}^{-1}$. Due to the nano-structured character of the calcined precursors, the surfaces consist of structurally/energetically different sites reflected in the low energy and broadness of the main peaks for $\mathrm{CO}$ adsorption on $\mathrm{CuO} / \mathrm{MgO}$ and $\mathrm{CuO} / \mathrm{ZnO}: \mathrm{Al}$, respectively. The peaks may contain several contributions. The signal of both calcined precursors at about $2100 \mathrm{~cm}^{-1}$ is proposed to be a result of partial surface reduction during calcination. From NEXAFS measurements at ambient pressure of the calcined $\mathrm{CuO} / \mathrm{ZnO}: \mathrm{Al}$ precursor, we know that a small fraction of $\mathrm{CuO}$ is already reduced to $\mathrm{Cu}_{2} \mathrm{O}$ (Fig. S7). The partially reduced surface is probed by the adsorption of $\mathrm{CO}$. Since no difference between the $\mathrm{ZnO}$-containing and the $\mathrm{ZnO}$-free calcined precursors was detected, the nano-structure of $\mathrm{CuO}$ in these materials is apparently comparable.

In contrast, major differences were observed after reduction of the two catalysts (Fig. 2). $\mathrm{Cu} / \mathrm{MgO}$ displays mainly a $\mathrm{CO}$ adsorption band at $2089 \mathrm{~cm}^{-1}$ with a shoulder at $2060 \mathrm{~cm}^{-1}$ well in agreement with the presence of metallic $\mathrm{Cu}$. Furthermore, from single crystal studies performed on differently oriented facets, it was inferred that closed packed surfaces as $\mathrm{Cu}(111)$ give rise to lower wavenumber signals at $2076 \mathrm{~cm}^{-1}$, and more open facets as (100) and (110) lead to signals at higher wavenumbers 2085 and $2093 \mathrm{~cm}^{-1}$, respectively [36]. The stretching frequency of $\mathrm{CO}$ on nanostructured, highly defective $\mathrm{Cu}$ surfaces is shifted to still higher wavenumbers $[10,15,36]$. The peak at $2089 \mathrm{~cm}^{-1}$ is consequently attributed to nano-structured metallic copper. The weak shoulder at $2114 \mathrm{~cm}^{-1}$, only observed at high coverage in the measurement at $77 \mathrm{~K}$, may indicate that the $\mathrm{Cu}$ component within a nano-structured $\mathrm{Cu} /$ metal oxide system is not completely reducible due to the intimate interfacial contact to the oxide part. $\mathrm{CO}$ adsorption was not found to take place on $\mathrm{MgO}$ at $300 \mathrm{~K}$. A weak signal for $\mathrm{CO}$ adsorption on $\mathrm{MgO}$ is visible at a band position of $2180 \mathrm{~cm}^{-1}$ if the $\mathrm{CO}$ adsorption was performed at low temperatures (Fig. 4, right) [39].

Compared to $\mathrm{Cu} / \mathrm{MgO}$, the intensity of the signals due to $\mathrm{CO}$ adsorbed on $\mathrm{Cu} / \mathrm{ZnO}: \mathrm{Al}$ catalyst is drastically diminished by about one order of magnitude after reduction (Fig. 5, middle). The band maximum is located at $2125 \mathrm{~cm}^{-1}$, which is neither typical for metallic $\mathrm{Cu}^{0}-\mathrm{CO}$ nor resembling the 
adsorption of $\mathrm{CO}$ on the calcined precursor or $\mathrm{CuO}$. The signal contains several contributions including a component at $2090 \mathrm{~cm}^{-1}$ attributed to nano-structured metallic copper. Substantial coverage of the metallic copper surface in the reduced $\mathrm{Cu} / \mathrm{ZnO}: \mathrm{Al}$ catalyst would be one plausible explanation for the high energy of the peak maximum and the low intensity of the signal. From previous XPS studies it is known, that under reducing conditions the surface of $\mathrm{Cu} /$ $\mathrm{ZnO}: \mathrm{Al}$ is highly enriched in $\mathrm{Zn}[21,28]$. Recent HR-TEM investigations provided further evidence for the formation of a zinc oxide overlayer [29]. Furthermore, we do not see any hints for a $\mathrm{Cu}-\mathrm{Zn}$ surface alloy formation under the applied conditions of reduction. The band position for $\mathrm{CO}$ adsorption on a CuZn alloy (or brass) sample is expected to arise at the same position $\left(2071 \mathrm{~cm}^{-1}\right)$ as metallic copper [40]. Adsorption of $\mathrm{CO}$ on $\mathrm{ZnO}$ at $77 \mathrm{~K}$ (Fig. S6, right) results in the formation of $\mathrm{Zn}^{2+}-\mathrm{CO}$ band at $2188-2180 \mathrm{~cm}^{-1}$ [3] The peaks usually disappear upon evacuation. Referring to the HR-TEM study, [29] the main peak at $2125 \mathrm{~cm}^{-1}$ is, therefore, tentatively attributed to adsorption of $\mathrm{CO}$ on the surface of a partially reduced $\mathrm{ZnO}$ overlayer $\left(\mathrm{Zn}^{\delta+}-\mathrm{CO}\right)$ or alternatively to not completely reduced $\mathrm{Cu}^{\delta+}-\mathrm{CO}$ species. Explicit discrimination between carbonyls of $\mathrm{Cu}^{\delta+}$ and $\mathrm{Zn}^{\delta+}$ is impossible based on the present experiments. The shoulder at $2112 \mathrm{~cm}^{-1}$ may be attributed to $\mathrm{Cu}$ defects, which are coordinatively and electronically unsaturated.

The stability of the carbonyls formed on $\mathrm{Cu} / \mathrm{ZnO}: \mathrm{Al}$ as well as on $\mathrm{Cu} / \mathrm{MgO}$ is low. Consequently, the $\mathrm{CO}$ desorption experiment (Fig. 3) provides no further hints in terms of an assignment. Interestingly, the additional band at $1996 \mathrm{~cm}^{-1}$, only observed on the $\mathrm{ZnO}$-containing catalyst (Fig. 3, left), is stable in vacuum. Formation of a $\mathrm{CuZn}_{\mathrm{x}}$ surface alloy is unlikely under the applied conditions, [41] since the peak is not observed when $\mathrm{CO}$ is adsorbed on $\mathrm{Cu} / \mathrm{ZnO} \mathrm{Al}$ reduced at higher temperatures. The assignment of the band at $1996 \mathrm{~cm}^{-1}$ requires further investigations. We may speculate at this point that the feature originates from adsorption of $\mathrm{CO}$ on the $\mathrm{Cu}-\mathrm{ZnO}_{1-\mathrm{x}}$ interface in a bridged position or on metallic $\mathrm{Cu}$ sites that are electronically modified by the interaction with $\mathrm{ZnO}_{1-\mathrm{x}}$.

In summary, the shift of the peak maximum of $\mathrm{CO}$ adsorbed on the reduced $\mathrm{Cu} / \mathrm{ZnO}$ : $\mathrm{Al}$ catalyst to higher energies in comparison with $\mathrm{Cu} / \mathrm{MgO}$ (Fig. 5, middle) indicates clearly that adsorption sites on metallic copper are largely not accessible in presence of $\mathrm{ZnO}$, which may be interpreted in terms of a coverage of the metallic copper surface with defective zinc oxide species as a result of the reductive treatment [29]. The low intensity of the signal of adsorbed $\mathrm{CO}$ may be interpreted in terms of a limited number of adsorption sites on the surface of the partially reduced $\mathrm{ZnO}$ overlayer or, more likely, in terms of a different absorption coefficient of $\mathrm{CO}$ adsorbed on $\mathrm{Zn}^{\delta+}-\mathrm{CO}$ compared to $\mathrm{Cu}^{0}-\mathrm{CO}$ [3]. Such a phenomenon is not observed when non-reducible
$\mathrm{MgO}$ is used as matrix for nano-structured copper. At this point it should be emphasized again that the domain size of the metallic copper determined by XRD is comparable for the two reduced catalysts (Table 1).

Adsorption of $\mathrm{CO}$ on $\mathrm{Cu} / \mathrm{MgO}$ at $77 \mathrm{~K}$ results in similar spectra as the adsorption of $\mathrm{CO}$ at room temperature, confirming an incompletely reduced character of $\mathrm{Cu}$ by the occurrence of a shoulder at $2114 \mathrm{~cm}^{-1}$ at high coverage. The partially oxidized $\mathrm{Cu}$ species are most probably located at the interface to the metal oxide (here $\mathrm{MgO}$ ). This hypothesis is supported by the results of NEXAFS measurements (Fig. S8), showing a not complete metallic $\mathrm{Cu}$ L-edge even under 1 bar $10 \%$ hydrogen at $523 \mathrm{~K}$.

In contrast, the spectra recorded at 300 and $77 \mathrm{~K}$ on the reduced $\mathrm{Cu} / \mathrm{ZnO}: \mathrm{Al}$ catalyst differ in terms of the peak positions, and also in intensity (Fig. 5, right). The main signal observed at $77 \mathrm{~K}$ at low CO coverage is located at $2096 \mathrm{~cm}^{-1}$ and can be attributed to metallic copper. Hence, contrary to the measurement at room temperature, where the $\mathrm{Cu}$ surface seemed to be almost completely blocked by the layered $\mathrm{ZnO}$ polymorph, $\mathrm{Cu}$ is exposed at least partly to gas phase $\mathrm{CO}$ at $77 \mathrm{~K}$. One explanation is, that the $\mathrm{ZnO}$ overlayer cracked mechanically due to different thermal expansion coefficients of $\mathrm{Cu}$ metal and $\mathrm{ZnO}$ when the reduced catalyst is cooled down to $77 \mathrm{~K}$. Only at higher CO pressures the overlayer becomes slowly visible again indicating that the encapsulation of $\mathrm{Cu}$ is re-established (Fig. 4, left). It has been reported that under reducing conditions, $\mathrm{ZnO}$ in contact with $\mathrm{Cu}$ becomes mobile leading to rearrangements [25].

\section{Conclusions}

In the present contribution the surface of copper embedded in a matrix of either $\mathrm{ZnO}: \mathrm{Al}$ or $\mathrm{MgO}$ has been studied by DRIFT spectroscopy applying carbon monoxide as probe molecule. It was found, that the adsorption of $\mathrm{CO}$ on metallic copper is substantially suppressed after activation of the high-performance $\mathrm{Cu} / \mathrm{ZnO}: \mathrm{Al}$ catalyst by a reductive treatment at $523 \mathrm{~K}$. In contrast, nano-structured metallic copper is accessible for gas-phase $\mathrm{CO}$ in the reduced $\mathrm{Cu} / \mathrm{MgO}$ catalyst. The signal of adsorbed $\mathrm{CO}$ that was detected for the $\mathrm{ZnO}$-containing catalyst differs from the signal usually observed after adsorption of $\mathrm{CO}$ on metallic copper. The results are in agreement with the adsorption of $\mathrm{CO}$ on $\mathrm{M}^{\delta+}$ $(\mathrm{M}=\mathrm{Zn}, \mathrm{Cu}$, but most likely $\mathrm{Zn})$ due to the formation of a thin layer of metastable "graphitic -/ boron nitride-like" $\mathrm{ZnO}$ on top of the metallic $\mathrm{Cu}$ particles previously detected by HR-TEM [29]. The DRIFTS study indicates that the local observation made by HR-TEM is representative for the entire catalyst surface. The coverage of metallic copper is not complete. Furthermore, our study shows that within a nanostructured $\mathrm{Cu} /$ metal oxide system, the $\mathrm{Cu}$-moieties are 
not completely reducible, most probably at the interfacial contact of the metal and the metal oxide. The importance of the $\mathrm{Cu} / \mathrm{ZnO}$ interface in reverse water-gas shift and methanol synthesis reactions was recently evidenced $[42,43]$.

The differences observed in methanol synthesis reactivity between $\mathrm{ZnO}$-containing and $\mathrm{ZnO}$-free catalysts in their active states could be related to a different nature of the surfaces that are exposed to the gas phase. The results demonstrate a step further towards an improved understanding of the synergistic effects in $\mathrm{Cu}-\mathrm{ZnO}$ based catalyst for methanol synthesis. In the present study reduced catalysts have been studied. The surface may change under reaction conditions [42]. Therefore, DRIFTS investigations of used catalysts transferred to the measurement cell without air contact and DRIFTS studies under operation at 30 bar pressure are currently underway.

Acknowledgements Open access funding provided by Max Planck Society.

Open Access This article is distributed under the terms of the Creative Commons Attribution 4.0 International License (http://creativecommons.org/licenses/by/4.0/), which permits unrestricted use, distribution, and reproduction in any medium, provided you give appropriate credit to the original author(s) and the source, provide a link to the Creative Commons license, and indicate if changes were made.

\section{References}

1. Zaera F (2014) New advances in the use of infrared absorption spectroscopy for the characterization of heterogeneous catalytic reactions. Chem Soc Rev 43:7624-7663

2. Lamberti C, Zecchina A, Groppo E, Bordiga S (2010) Probing the surfaces of heterogeneous catalysts by in situ IR spectroscopy. Chem Soc Rev 39:4951-5001

3. Hadjiivanov KI, Vayssilov GN (2002) Characterization of oxide surfaces and zeolites by carbon monoxide as an IR probe molecule. Adv Catal 47:307-511

4. Knözinger H (2008) Infrared spectroscopy for the characterization of surface acidity and basicity. Handbook of heterogeneous catalysis. Wiley, New Jersey

5. Hadjiivanov K, Knözinger H (2009) Characterization of vacant coordination sites of cations on the surfaces of oxides and zeolites using infrared spectroscopy of adsorbed probe molecules. Surf Sci 603:1629-1636

6. Zaera F (2012) Infrared absorption spectroscopy of adsorbed co: new applications in nanocatalysis for an old approach. ChemCatChem 4:1525-1533

7. Bordiga S, Lamberti C, Bonino F, Travert A, Thibault-Starzyk F (2015) Probing zeolites by vibrational spectroscopies. Chem Soc Rev 44:7262-7341

8. Carenco S (2014) Carbon monoxide-induced dynamic metalsurface nanostructuring. Chem Eur J 20:10616-10625

9. Sun Q, Liu C-W, Pan W, Zhu Q-M, Deng J-F (1998) In situ IR studies on the mechanism of methanol synthesis over an ultrafine $\mathrm{Cu} / \mathrm{ZnO} / \mathrm{A} 12 \mathrm{O} 3$ catalyst. Appl Catal A 171:301-308

10. Sakakini BH, Tabatabaei J, Watson MJ, Waugh KC (2000) Structural changes of the $\mathrm{Cu}$ surface of a $\mathrm{Cu} / \mathrm{ZnO} / \mathrm{Al}_{2} \mathrm{O}_{3}$ catalyst, resulting from oxidation and reduction, probed by $\mathrm{CO}$ infrared spectroscopy. J Mol Catal A 162:297-306

11. Martin O, Mondelli C, Cervellino A, Ferri D, Curulla-Ferré D, Pérez-Ramírez J (2016) Operando synchrotron X-ray powder diffraction and modulated-excitation infrared spectroscopy elucidate the $\mathrm{CO}_{2}$ promotion on a commercial methanol synthesis catalyst. Angew Chem Int Ed 55:11031-11036

12. Bailey S, Froment GF, Snoeck JW, Waugh KC (1994) A DRIFTS study of the morphology and surface adsorbate composition of an operating methanol synthesis catalyst. Catal Lett 30:99-111

13. Kanai Y, Watanabe T, Fujitani T, Saito M, Nakamura J, Uchijima $\mathrm{T}$ (1994) Evidence for the migration of $\mathrm{ZnOx}$ in a $\mathrm{Cu} / \mathrm{ZnO}$ methanol synthesis catalyst. Catal Lett 27:67-78

14. Bailie JE, Rochester CH, Millar GJ (1995) Spectroscopic evidence for adsorption sites located at $\mathrm{Cu} / \mathrm{ZnO}$ interfaces. Catal Lett 31:333-340

15. Topsøe N-Y, Topsøe H (1999) FTIR studies of dynamic surface structural changes in $\mathrm{Cu}$-based methanol synthesis catalysts1. J Mol Catal A 141:95-105

16. Naumann d'Alnoncourt R, Bergmann M, Strunk J, Löffler E, Hinrichsen O, Muhler M (2005) The coverage-dependent adsorption of carbon monoxide on hydrogen-reduced copper catalysts: the combined application of microcalorimetry, temperature-programmed desorption and FTIR spectroscopy. Thermochim Acta 434:132-139

17. Naumann d'Alnoncourt R, Xia X, Strunk J, Loffler E, Hinrichsen O, Muhler M (2006) The influence of strongly reducing conditions on strong metal-support interactions in $\mathrm{Cu} / \mathrm{ZnO}$ catalysts used for methanol synthesis. Phys Chem Chem Phys 8:1525-1538

18. Millar GJ, Rochester CH, Waugh KC (1991) Infrared study of $\mathrm{CO}$ adsorption on reduced and oxidised silica-supported copper catalysts. J Chem Soc Faraday Trans 87:1467-1472

19. Yang Y, Mei D, Peden CHF, Campbell CT, Mims CA (2015) Surface-Bound intermediates in low-temperature methanol synthesis on copper: participants and spectators. ACS Catal 5:7328-7337

20. Zander S, Kunkes EL, Schuster ME, Schumann J, Weinberg G, Teschner D et al (2013) The role of the oxide component in the development of copper composite catalysts for methanol synthesis. Angew Chem Int Ed 52:6536-6540

21. Schumann J, Lunkenbein T, Tarasov A, Thomas N, Schlögl R, Behrens M (2014) Synthesis and characterisation of a highly active $\mathrm{Cu} / \mathrm{ZnO}: \mathrm{Al}$ catalyst. ChemCatChem 6:2889-2897

22. Studt F, Behrens M, Kunkes EL, Thomas N, Zander S, Tarasov A et al (2015) The mechanism of $\mathrm{CO}$ and $\mathrm{CO}_{2}$ hydrogenation to methanol over $\mathrm{Cu}$-based catalysts. ChemCatChem 7:1105-1111

23. Kanai Y, Watanabe T, Fujitani T, Uchijima T, Nakamura J (1996) The synergy between $\mathrm{Cu}$ and $\mathrm{ZnO}$ in methanol synthesis catalysts. Catal Lett 38:157-163

24. Spencer MS (1999) The role of zinc oxide in $\mathrm{Cu} / \mathrm{ZnO}$ catalysts for methanol synthesis and the water-gas shift reaction. Top Catal $8: 259-266$

25. Grunwaldt JD, Molenbroek AM, Topsøe NY, Topsøe H, Clausen BS (2000) In situ investigations of structural changes in $\mathrm{Cu} / \mathrm{ZnO}$ catalysts. J Catal 194:452-460

26. Jansen WPA, Beckers J, Heuvel JC, Denier VD, Gon AW, Bliek A, Brongersma HH (2002) Dynamic behavior of the surface structure of $\mathrm{Cu} / \mathrm{ZnO} / \mathrm{SiO}_{2}$ catalysts. J Catal 210:229-236

27. Liao F, Huang Y, Ge J, Zheng W, Tedsree K, Collier P et al (2011) Morphology-dependent interactions of $\mathrm{ZnO}$ with $\mathrm{Cu}$ nanoparticles at the materials' interface in selective hydrogenation of $\mathrm{CO}_{2}$ to $\mathrm{CH}_{3} \mathrm{OH}$. Angew Chem Int Ed 50:2162-2165

28. Behrens M, Studt F, Kasatkin I, Kühl S, Hävecker M, Abild-Pedersen $\mathrm{F}$ et al (2012) The active site of methanol synthesis over $\mathrm{Cu} /$ $\mathrm{ZnO} / \mathrm{A} 12 \mathrm{O} 3$ industrial catalysts. Science 336:893-897

29. Lunkenbein T, Schumann J, Behrens M, Schlögl R, Willinger MG (2015) Formation of a $\mathrm{ZnO}$ overlayer in industrial $\mathrm{Cu} / \mathrm{ZnO} / \mathrm{Al} 2 \mathrm{O} 3$ 
catalysts induced by strong metal-support Interactions. Angew Chem Int Ed 54:4544-4548

30. Sirita J, Phanichphant S, Meunier FC (2007) Quantitative analysis of adsorbate concentrations by diffuse reflectance FT-IR. Anal Chem 79:3912-3918

31. Olinger JM, Griffiths PR (1988) Quantitative effects of an absorbing matrix on near-infrared diffuse reflectance spectra. Anal Chem 60:2427-2435

32. Kortüm G, Braun W, Herzog G (1963) Principles and techniques of diffuse-reflectance spectroscopy. Angew Chem Int Ed 2:333-341

33. Fichtl MB, Schumann J, Kasatkin I, Jacobsen N, Behrens M, Schlögl R et al (2014) Counting of oxygen defects versus metal surface sites in methanol synthesis catalysts by different probe molecules. Angew Chem Int Ed 53:7043-7047

34. Eischens RP, Pliskin WA (1958) The infrared spectra of adsorbed molecules. In: Advances in catalysis Eley WGFVIK DD, Paul BW pp 1-56. Academic Press, Cambridge

35. Smith AW, Quets JM (1965) Adsorption of carbon monoxide on copper. J Catal 4:163-171

36. Pritchard J, Catterick T, Gupta RK (1975) Infrared spectroscopy of chemisorbed carbon monoxide on copper. Surf Sci 53:1-20

37. Hayden BE, Kretzschmar K, Bradshaw AM (1985) An infrared spectroscopic study of $\mathrm{CO}$ on $\mathrm{Cu}(111)$ : the linear, bridging and physisorbed species. Surf Sci 155:553-566
38. Hollins P, Pritchard J (1979) Interactions of CO molecules adsorbed on $\mathrm{Cu}(111)$. Surf Sci 89:486-495

39. Spoto G, Gribov EN, Ricchiardi G, Damin A, Scarano D, Bordiga $\mathrm{S}$ et al (2004) Carbon monoxide $\mathrm{MgO}$ from dispersed solids to single crystals: a review and new advances. Prog Surf Sci 76:71-146

40. Schott V, Oberhofer H, Birkner A, Xu M, Wang Y, Muhler M et al (2013) Chemical activity of thin oxide layers: strong interactions with the support yield a new thin-film phase of $\mathrm{ZnO}$. Angew Chem Int Ed 52:11925-11929

41. Liu Z, Rittermeier A, Becker M, Kähler K, Löffler E, Muhler M (2011) High-pressure CO adsorption on Cu-based catalysts: Zninduced formation of strongly bound CO monitored by ATR-IR spectroscopy. Langmuir 27:4728-4733

42. Lunkenbein T, Girgsdies F, Kandemir T, Thomas N, Behrens M, Schlögl R et al (2016) Bridging the time gap: a copper/zinc oxide/ aluminum oxide catalyst for methanol synthesis studied under industrially relevant conditions and time scales. Angew Chem Int Ed. doi:10.1002/anie.201603368

43. Álvarez Galván C, Schumann J, Behrens M, Fierro JLG, Schlögl $\mathrm{R}$, Frei $\mathrm{E}$ (2016) Reverse water-gas shift reaction at the $\mathrm{Cu} / \mathrm{ZnO}$ interface: influence of the $\mathrm{Cu} / \mathrm{Zn}$ ratio on structure-activity correlations. Appl Catal B 195:104-111 